Jurnal Tabarru' : Islamic Banking and Finance

Volume 3 Nomor 1, Mei 2020

p-ISSN 2621-6833

e-ISSN 2621-7465

\title{
PENGARUH PEMBIAYAAN MURABAHAH DAN MUSYARAKAH TERHADAP PROFITABILITAS BANK UMUM SYARIAH PERIODE 2016-2018
}

\author{
Rahma Disa Putri \\ Fakultas Agama Islam (FAI), Universitas Islam Riau (UIR) \\ Email: rahmadisaputri@student.uir.ac.id
}

\begin{abstract}
ABSTRAK
Penelitian ini dilakukan untuk menguji pengaruh variabel murabahah dan musyarakah terhadap profitabilitas bank umum syariah yang terdaftar di Bank Indonesia (BI) periode 2016-2018. Populasi penelitian ini adalah bank umum syariah yang terdaftar di BI yaitu sebanyak 14 perusahaan. Berdasarkan teknik purposive sampling di dapatkan sampel sebanyak 12 perusahaan. Penelitian ini menggunakan metode dokumentasi yang di dapat dari laporan keuangan yang dipublikasikan di website www.ojk.go.id. Teknik analisis yang digunakan adalah regresi linear berganda. Hasil penelitian menunjukkan bahwa: (1) Murabahah berpengaruh positif dan siginifikan terhadap profitabilitas, dan (2) Musyarakah berpengaruh siginifikan negatif terhadap profitabilitas.
\end{abstract}

Kata Kunci : Murabahah, Musyarakah, Profitabilitas.

\begin{abstract}
This research was conducted to examine the effect of variables Murabaha and Musyaraka to Profitability at Islamic Banks registered in Indonesian Banks 2016-2018 period. The population of this research is 14 Islamic Banks registered with BI. Based on purposive sampling technique, a sample of 12 companies was obtained. This research uses the documentation method obtained from the financial statements published on the website www.ojk.go.id. the analysis technique use is multiple linier regression. The research showed that: (1) Murabaha had a positive and significant effect on Profitability, and (2) Musyaraka had negative significant effect on Profitability.
\end{abstract}

Keywords : Murabaha, Musyaraka, Profitability. 


\section{PENDAHULUAN}

Bank syariah adalah lembaga keuangan yang berfungsi untuk menghimpun dana dari pihak yang kelebihan dana dan menyalurkannya kepada pihak yang kekurangan dana untuk kegiatan usaha atau kegiatan lainnya yang sesuai dengan akad yang telah ditentukan dan operasionalnya sesuai dengan syariah Islam. Bank syariah yang pertama kali didirikan adalah Bank Muamalat Indonesia (BMI) yang didirikan pada tahun 1992. Pada tahun 2019 jumlah bank syariah di Indonesia menjadi 198, yaitu 14 Bank Umum Syariah (BUS), 20 Unit Usaha Syariah (UUS) dan BPRS hingga tahun 2019 menjadi 164 unit.

Pentingnya perbankan dalam hal meningkatkan pembangunan perekonomian Indonesia, sehingga menurut Peraturan Bank Indonesia Nomor: 13/1/PBI/2011 Tentang Penilaian Kesehatan Bank Umum, bank diwajibkan untuk selalu memelihara dan meningkatkan tingkat kesehatan bank. Penilaian kesehatan bank dapat dilihat dari kinerja bank tersebut. Analisis kinerja bank dapat dilihat dari profitabilitas bank umum syariah. Profitabilitas adalah produktivitas bank dalam mengelola uang untuk mendapatkan keuntungan.

Pembiayaam menurut Kasmir (2008) adalah penyediaan uang atau tagihan yang dipersamakan dengan itu, berdasarkan persetujuan atau kesepakatan antara bank dengan pihak lain yang mewajibkan pihak yang dibiayai untuk mengembalikan uang atau tagihan tersebut setelah jangka waktu tertentu dengan imbalan atau bagi hasil. Dengan adanya pembiayaan bisa membantu pihak yang membutuhkan dan kekurangan dana.

Beberapa penelitian yang sama, pada penelitian Fadholi (2015), yang berjudul pengaruh pembiayaan murabahah, musyarakah dan mudharabah terhadap profitabilitas bank umum syariah hasil penelitian menunjukkan bahwa pembiayaan murabahah dan musyarakah berpengaruh signifikan terhadap ROA, sedangkan mudharabah memberikan pengaruh signifikan dan positif terhadap ROA.
Selanjutnya dalam penelitian Puteri, dkk (2014) yang berjudul pengaruh pembiayaan mudharabah, musyarakah, murabahah, Istishna dan Ijarah terhadap profitabilitas bank umum syariah di Indonesia, hasil penelitian menunjukkan mudharabah dan musyarakah berpengaruh signifikan negatif sedangkan murabahah, istishna dan ijarah berpengaruh signifikan positif terhadap profitabilitas pada bank umum syariah, dalam penelitian Sari dan Afif (2015) yang berjudul pengaruh pembiayaan mudharabah, pembiayaan musyarakah, dan pembiayaan murabahah terhadap profitabilitas pada Bank Syariah Mandiri dan Bank Muamalat Indonesia (Studi pada Bank Umum Syariah yang terdaftar di Indonesia periode Triwulan I 2007- Triwulan IV 2014), hasil penelitiannya menunjukkan bahwa mudharabah dan musyarakah berpengaruh signifikan terhadap profitabilitas dan murabahah berpengaruh signifikan dan negatif terhadap profitabilitas. Dan selanjutnya penelitian Melina dan Zulfa (2020) yang berjudul Implementasi Pembiayaan Murabahah pada Baitul Mal Wat Tamwil (BMT) Kota Pekanbaru yang hasil penelitiannya menyatakan bahwa harga perolehan dan keuntungan yang diterapakan BMT Kota Pekanbaru sesuai dengan kesepakatan bersama antara pengelola dan pembeli.

\section{TINJAUAN PUSTAKA}

\section{Pembiayaan Murabahah}

Karim (2008) mendefinisikan murabahah berarti suatu penjualan barang seharga barang tersebut ditambah keuntungan yang disepakati. Misalnya, seseorang membeli barang kemudian menjualnya kembali dengan keuntungan tertentu. Berapa besar keuntungan tersebut dapat dinyatakan dalam nominal rupiah tertentu atau dalam bentuk persentase dari harga pembeliannya, misalnya $10 \%$ atau $20 \%$.

Murabahah adalah perjanjian jual beli antara bank dan nasabah di mana bank syariah membeli barang yang diperlukan oleh nasabah dan kemudian menjualnya kepada nasabah yang bersangkutan sebesar 
harga perolehan ditambah dengan margin/keuntungan yang disepakati antara bank syariah dan nasabah (Muhammad, 2005)

Melalui pembiayaan murabahah, bank syariah akan memperoleh profit berupa pendapatan penjualan dari harga pokok yang telah ditetapkan pihak bank.

\section{Pembiayaan Musyarakah}

Menurut Sjahdeini (1999) pengertian musyarakah adalah "kemitraan antara pihak bank dan pihak nasabah untuk bersamasama memberikan modal dengan cara membeli saham untuk membiayai investasi”.

Menurut Wiroso dan Yusuf (2010), musyarakah adalah "akad kerja sama diantara para pemilik modal yang mencampurkan modal mereka untuk tujuan mencari keuntungan.

Melalui pembiayaan musyarakah yang disalurkan, bank syariah akan memperoleh profit berupa bagi hasil yang menjadi bagian bank. Dari pengelolaan pembiayaan bagi hasil, bank syariah memperoleh pendapatan bagi hasil sesuai dengan nisbah yang telah disepakati dengan nasabah (Muhammad, 2005).

\section{Profitabilitas}

Rasio Profitabilitas merupakan perbandingan laba dengan total aset yang dimiliki bank pada periode tertentu. Agar hasil perhitungan rasio mendekati pada kondisi yang sebenarnya, maka posisi modal atau aset dihitung secara rata-rata selama periode tersebut.

Analisis rasio profitabilitas dalam penelitian ini menggunakan perhitungan Return on Assets (ROA), karena lebih akurat. Sedangkan ROE lebih cocok digunakan untuk mengukur profitabilitas pada perusahaan dan NPMR lebih cocok digunakan untuk mengukur profitabilitas pada perusahaan manufaktur. Rasio-rasio ini digunakan untuk mengukur kemampuan manajemen bank dalam memperoleh keuntungan (laba) secara keseluruhan. Semakin besar ROA suatu bank, semakin besar pula tingkat keuntungan yang dicapai bank tersebut dan semakin baik pula posisi bank tersebut dari segi penggunaan asset.

Rumus Perhitungan ROA adalah :

$\mathrm{ROA}=\underline{\text { Laba sebelum pajak disetahunkan }}$

Rata-rata total aset

Dalam penelitian ini alasan menggunakan rasio profitabilitas adalah rasio ini merupakan metode pengukuran yang obyektif dan didasarkan pada data akutansi yang tersedia. Besarnya ROA dapat mencerminkan hasil dari serangkaian kebijakan bank.

\section{METODE PENELITIAN}

\section{Tempat dan waktu penelitian}

Penelitian ini dilakukan pada 12 bank umum syariah dan bank yang dipilih menjadi sampel yang hanya terdaftar di Otoritas Jasa dan Keuangan (OJK) yang memiliki data laporan publikasi keuangan, data laporan tahunan yang diambil dari situs resmi www.ojk.go.id dari tahun 2016-2018.

\section{Populasi dan Sampel}

Populasi adalah kumpulan dari semua objek atau individu yang memiliki karakteristik, jelas dan lengkap yang akan diteliti (bahan penelitian). Populasi yang digunakan dalam penelitian ini adalah semua bank umum syariah di Indonesia yang terdaftar di direktori Bank Indonesia periode 2014-2018 yaitu sebanyak 14 bank umum syariah.

Pemilihan sampel dalam penelitian ini menggunakan metode purposive sampling, menurut Usman dan Akbar (2008) metode ini digunakan apabila anggota sampel yang dipilih secara khusus berdasarkan tujuan penelitian yaitu memilih karakteristik tertentu sebagai kunci untuk dijadikan sampel, sedangkan yang tidak masuk dalam karakteristik yang ditentukan akan diabaikan atau tidak dijadikan sampel. Adapun kriteria yang digunakan untuk menentukan sampel dalam penelitian ini, yaitu :

a. Bank Umum Syariah harus menyediakan laporan keuangan secara lengkap selama 
periode 2016-2018 terkait dengan adanya nilai murabahah, musyarakah dan ROA;

b. Laporan keuangan yang disediakan merupakan laporan keuangan tahunan pada periode 2016-2018 yang telah dipublikasikan di Bank Indonesia atau pada website masing-masing bank syariah tersebut;

c. Laporan keuangan harus memiliki tahun buku yang berakhir 31 Desember, karena hal ini untuk menghindari adanya pengaruh waktu parsial dalam perhitungan proksi dari variabel independen maupun dependen; d. Bank Umum Syariah di Indonesia memiliki data yang dibutuhkan terkait pengukuran variabel-variabel yang digunakan untuk penelitian selama periode 2016-2018.

Berdasarkan metode Purposive Sampling tersebut, tercatat ada dua belas (12) sampel yang digunakan dalam penelitian ini. bank umum syariah yang dijadikan sampel dalam penelitian ini tercatat pada tabel berikut:

\begin{tabular}{cc}
\hline No & Tabel 1. Sampel Penelitian \\
\hline 1 & PT. BANK Bank Umum Syariah \\
\hline 2 & PT. VICTORIA SYARIAH \\
\hline 3 & PT. BANK BRI SYARIAH \\
\hline 4 & PT. BANK JABAR BANTEN SYARIAH \\
\hline 5 & PT. BANK BNI SYARIAH \\
\hline 6 & PT. BANK SYARIAH MANDIRI \\
\hline 7 & PT. BANK MEGA SYARIAH \\
\hline 8 & PT. BANK PANIN DUBAI SYARIAH \\
\hline 9 & PT. BANK SYARIAH BUKOPIN \\
\hline 10 & PT. BANK BCA SYARIAH \\
\hline 11 & PT. MAYBANK SYARIAH \\
\hline 12 & PT. BANK ACEH \\
\hline Sumber: Data Publikasi OJK $2016-2018$
\end{tabular}

\section{Jenis Penelitian}

Data yang dikumpulkan dalam penelitian ini merupakan data sekunder, yaitu jenis data yang diproleh secara tidak langsung dari sumber utama (perusahaan). Data dalam penelitian ini berupa laporan tahunan dari perusahaan yang terpilih menjadi sampel. Data dalam penelitian ini diproleh dari laporan tahunan perusaahan yang terdaftar dalam OJK tahun 2016-2018. Data diproleh dengan cara mengakses situs otoritas jasa keuangan (www.ojk.go.id).

\section{Teknik Analisis Data}

\section{Analisis regresi linier berganda}

Analisis linier berganda akan dilakukan bila jumlah variabel independennya minimal 2. Menurut Sugiyono (2014) persamaan regresi linier berganda yang ditetapkan adalah sebagai berikut :

$$
\mathbf{Y}=\mathbf{a}+\mathbf{b}_{1} \mathbf{x}_{1}+\mathbf{b}_{2} \mathbf{x}_{2}+\mathbf{\epsilon}
$$

Keterangan :

$$
\begin{array}{ll}
\mathrm{Y} & =\text { ROA } \\
\mathrm{a} & =\text { Koefisien konstanta } \\
\mathrm{b} & =\text { Koefisien regresi } \\
\mathrm{x}_{1} & =\text { Murabahah } \\
\mathrm{x}_{2} & =\text { Musyarakah } \\
\epsilon & =\text { error }
\end{array}
$$

\section{HASIL PENELITIAN DAN PEMBAHASAN}

\section{Hasil Penelitian}

Penelitian ini menganalisis kinerja Bank Umum Syariah di Indonesia tahun 2016-2018. Objek penelitian terdiri dari 12 Bank Umum Syariah yang meliputi Bank BRISyariah, Bank Mega syariah, Bank 
Syariah Mandiri, Bank Muamalat Indonesia, Bank Panin Dubai Syariah, Bank BNI Syariah, Bank Maybank Syariah, Bank Syariah Bukopin, Bank BCA Syariah, Bank Analisis Deskriptif Variabel Murabahah
Jabar Banten Syariah, Bank Victoria Syariah, dan Bank Aceh. Data yang digunakan adalah laporan keuangan Triwulan pada periode 2016-2018.

Tabel 2. Analisis Deskriptif Variabel Murabahah

\begin{tabular}{|c|c|c|c|c|c|}
\hline \multirow{2}{*}{ No } & \multirow{2}{*}{ Nama Bank } & \multicolumn{3}{|c|}{ Murabahah (X1) } & \multirow[b]{2}{*}{ Rata-rata } \\
\hline & & 2016 & 2017 & 2018 & \\
\hline 1 & $\begin{array}{l}\text { BANK BRI } \\
\text { SYARIAH }\end{array}$ & $15,100,133.00$ & $15,083,878.00$ & $16,008,95$ & $15,092,005.50$ \\
\hline 2 & $\begin{array}{l}\text { BANK } \\
\text { MUAMALAT } \\
\text { INDONESIA }\end{array}$ & $23,314,380.00$ & $27,016,190.00$ & $2,161,800.00$ & $17,497,456.67$ \\
\hline 3 & $\begin{array}{l}\text { BANK SYARIAH } \\
\text { MANDIRI }\end{array}$ & $53,201,180.00$ & $54,783,980.00$ & $59,393,119.00$ & $55,792,759.67$ \\
\hline 4 & $\begin{array}{l}\text { BANK MEGA } \\
\text { SYARIAH } \\
\end{array}$ & $4,993,290.00$ & $4,456,030.00$ & $4,384,720.00$ & $4,611,346.67$ \\
\hline 5 & $\begin{array}{l}\text { BANK SYARIAH } \\
\text { BUKOPIN }\end{array}$ & $3,093,885.00$ & $2,598,508.00$ & $2,279,713.00$ & $2,657,368.67$ \\
\hline 6 & $\begin{array}{l}\text { BANK BNI } \\
\text { SYARIAH }\end{array}$ & $24,980,801.00$ & $27,265,631.00$ & $29,349,587.00$ & $27,198,673.00$ \\
\hline 7 & $\begin{array}{l}\text { BANK BJB } \\
\text { SYARIAH }\end{array}$ & $7,461,626.00$ & $7,494,640.00$ & $5,213,356.00$ & $6,723,207.33$ \\
\hline 8 & $\begin{array}{l}\text { BANK BCA } \\
\text { SYARIAH }\end{array}$ & $2,017,722.00$ & $2,153,936.00$ & $2,342,470.00$ & $2,171,376.00$ \\
\hline 9 & $\begin{array}{l}\text { BANK VICTORIA } \\
\text { SYARIAH }\end{array}$ & $352,207.00$ & $413,009.00$ & $323,580.00$ & $362,932.00$ \\
\hline 10 & $\begin{array}{l}\text { BANK MAYBANK } \\
\text { SYARIAH }\end{array}$ & $1,002,770.00$ & $609,365.00$ & $118,274.00$ & $576,803.00$ \\
\hline 11 & $\begin{array}{l}\text { BANK PANIN } \\
\text { DUBAI SYARIAH }\end{array}$ & $1,206,560.00$ & $1,213,420.00$ & $590,244.00$ & $1,003,408.00$ \\
\hline 12 & BANK ACEH & $20,071,030.00$ & $21,170,710.00$ & $20,905,668.00$ & $20,715,802.67$ \\
\hline & Maksimum & 53201180.000 & 54783980.000 & 59393119.000 & \\
\hline & Minimum & 352207.000 & 413009.000 & 118274.000 & \\
\hline & Rata-rata & 13066298.667 & 13688274.750 & 11551139.182 & \\
\hline
\end{tabular}

Analisis Deskriptif Variabel Musyarakah

Tabel 3. Deskriptif Variabel Musyarakah

\begin{tabular}{|c|c|c|c|c|c|}
\hline \multirow{2}{*}{ No } & \multirow{2}{*}{ Nama Bank } & \multicolumn{3}{|c|}{ Musyarakah (X2) } & \multirow[b]{2}{*}{ Rata-rata } \\
\hline & & 2016 & 2017 & 2018 & \\
\hline 1 & BANK BRI SYARIAH & $5,379,830.00$ & $5,572,220.00$ & $7,748,129.00$ & $6,233,393.00$ \\
\hline 2 & $\begin{array}{l}\text { BANK MUAMALAT } \\
\text { INDONESIA }\end{array}$ & $20,900,783.00$ & $19,857,952.00$ & $16,543,871.00$ & $19,100,868.67$ \\
\hline 3 & $\begin{array}{l}\text { BANK SYARIAH } \\
\text { MANDIRI }\end{array}$ & $13,338,662.00$ & $17,640,213.00$ & $21,449,077.00$ & $17,475,984.00$ \\
\hline 4 & $\begin{array}{l}\text { BANK MEGA } \\
\text { SYARIAH } \\
\end{array}$ & $343,812.00$ & $663,112.00$ & $1,260,486.00$ & $755,803.33$ \\
\hline 5 & $\begin{array}{l}\text { BANK SYARIAH } \\
\text { BUKOPIN }\end{array}$ & $2,178,803.00$ & $2,568,412.00$ & $2,589,987.00$ & $2,445,734.00$ \\
\hline 6 & BANK BNI SYARIAH & $3,012,748.00$ & $4,586,209.00$ & $7,325,664.00$ & $4,974,873.67$ \\
\hline 7 & BANK BJB SYARIAH & $830,645.00$ & $819,852.00$ & $1,131,772.00$ & $927,423.00$ \\
\hline 8 & $\begin{array}{l}\text { BANK BCA } \\
\text { SYARIAH }\end{array}$ & $1,300,822.00$ & $1,834,415.00$ & $2,432,321.00$ & $1,855,852.67$ \\
\hline
\end{tabular}


2020, Jurnal Tabarru' : Islamic Banking and Finance 3 (1) : 48 - 56

\begin{tabular}{|c|c|c|c|c|c|}
\hline 9 & $\begin{array}{l}\text { BANK VICTORIA } \\
\text { SYARIAH }\end{array}$ & $929,535.00$ & $868,014.00$ & $930,419.00$ & $909,322.67$ \\
\hline 10 & $\begin{array}{l}\text { BANK MAYBANK } \\
\text { SYARIAH }\end{array}$ & $222,964.00$ & $37,801.00$ & - & $86,921.67$ \\
\hline 11 & $\begin{array}{l}\text { BANK PANIN DUBAI } \\
\text { SYARIAH }\end{array}$ & $4,721,855.00$ & $5,022,793.00$ & $5,465,099.00$ & $5,069,915.67$ \\
\hline \multirow[t]{4}{*}{12} & BANK ACEH & $5,379,830.00$ & $5,572,220.00$ & $7,748,129.00$ & $6,233,393.00$ \\
\hline & Maksimum & $20,900,783.00$ & $19,857,952.00$ & $21,449,077.00$ & \\
\hline & Minimum & $222,964.00$ & $37,801.00$ & - & \\
\hline & Rata-rata & $4,878,357.42$ & $5,420,267.75$ & $6,218,746.17$ & \\
\hline
\end{tabular}

Sumber : Data Olahan (2019)

Analalisis Deskriptif Variabel Profitabilitas

Tabel 4. Deskriptif Variabel Profitabilitas

\begin{tabular}{clcccc}
\hline \multirow{2}{*}{ No } & & \multicolumn{2}{c}{ Profitabilitas (ROA) Y } & \multirow{2}{*}{ Rata-rata } \\
\cline { 3 - 5 } & & 2016 & 2017 & 2018 & 0.630 \\
\hline 2 & BANK BRI SYARIAH & 0.950 & 0.510 & 0.430 & 0.137 \\
\hline 3 & BANK MUAMALAT INDONESIA & 0.220 & 0.110 & 0.080 & 0.687 \\
\hline 4 & BANK MEGA SYARIAH & 0.590 & 0.590 & 0.880 & 1.707 \\
\hline 5 & BANK SYARIAH BUKOPIN & 2.630 & 1.560 & 0.930 & 0.267 \\
\hline 6 & BANK BNI SYARIAH & 0.760 & 0.020 & 0.020 & 1.390 \\
\hline 7 & BANK BJB SYARIAH & 1.440 & 1.310 & 1.420 & -4.410 \\
\hline 8 & BANK BCA SYARIAH & -8.080 & -5.690 & 0.540 & 1.157 \\
\hline 9 & BANK VICTORIA SYARIAH & 1.130 & 1.170 & 1.170 & -0.500 \\
\hline 10 & BANK MAYBANK SYARIAH & -2.180 & 0.360 & 0.320 & -3.623 \\
\hline 11 & BANK PANIN DUBAI SYARIAH & -9.510 & 5.500 & -6.860 & -3.380 \\
\hline 12 & BANK ACEH & 0.370 & -10.770 & 0.260 & 1.803 \\
\hline & Maksimum & 2.630 & 5.500 & 2.380 & \\
\hline & Minimum & -9.510 & -10.770 & -6.860 & \\
\hline & Rata-rata & -0.930 & -0.235 & 0.131 & \\
\hline
\end{tabular}

Sumber : Data Olahan (2019)

Analisis Deskriptif Statistik

Tabel 5. Deskriptif Statistik

\begin{tabular}{rrrrr}
\hline Variabel & \multicolumn{1}{l}{ Mean } & \multicolumn{1}{c}{ Std. Deviation } & $\mathrm{N}$ \\
\hline $\mathrm{Y}$ &,- 4319 & 3,65075 & 36 \\
\hline $\mathrm{X} 1$ & 6705518,5067 & 11697653,92325 & 36 \\
\hline $\mathrm{X} 2$ & 5044972,5000 & 6454885,11544 & 36 \\
\hline
\end{tabular}

Sumber: Data Olahan (2019)

1. Jumlah observasi dalam penelitian ini sebanyak 36 data selama periode 20162018. Nilai rata-rata (mean) ROA sebesar $-0,4319$ dengan standar deviasinya sebesar 3,65075, yang artinya nilai mean lebih kecil daripada standar deviasinya sehingga mengindikasikan hasil yang tidak baik karena semakin besar nilai standar deviasi maka semakin besar kemungkinan nilai riil menyimpang dari yang diharapkan.

2. Nilai rata-rata murabahah sebesar 6705518,5067 dengan standar deviasi sebesar 11697653,92325 yang artinya nilai mean lebih kecil daripada standar deviasinya sehingga mengindikasikan hasil yang tidak baik karena semakin besar nilai standar deviasi maka semakin 
besar kemungkinan nilai riil menyimpang dari yang diharapkan.

3. Nilai rata-rata musyarakah sebesar 5044972,5000 dengan standar deviasi sebesar 6454885,11544 artinya nilai mean lebih kecil daripada standar deviasinya sehingga mengindikasikan hasil yang tidak baik karena semakin besar nilai standar deviasi maka semakin besar kemungkinan nilai riil menyimpang dari yang diharapkan.

\section{Uji F (Uji Simultan)}

Tabel 6. Uji Simultan

\begin{tabular}{crr}
\hline Variabel & F & \multicolumn{1}{c}{ Sig. } \\
\hline Murabahah & .200 & $.820^{\mathrm{b}}$ \\
\hline Musyarakah & .200 & $.820^{\mathrm{b}}$ \\
\hline
\end{tabular}

Sumber : Data Olahan (2019)

Di dapat $F_{\text {hitung }}$ sebesar 0,200 dan nilai $F_{\text {tabel }}$ sebesar 8. sehingga hipotesis pertama yang menyatakan bahwa variabel $\mathrm{X}$ (murabahah dan musyarakah) berpengaruh secara simultan terhadap variabel Y (ROA) pada Bank Umum Syariah.

\section{Koefisien Determinasi}

\section{Tabel 7. Koefisien Determinasi}

\begin{tabular}{cr}
\hline Variabel & \multicolumn{2}{c}{ Adjusted R Square } \\
\hline Murabahah & .48 \\
\hline Musyarakah & .48 \\
\hline \multicolumn{2}{c}{ Sumber : Data Olahan (2019) }
\end{tabular}

Variabel murabahah dan musyarakah berpengaruh terhadap ROA sebesar 0,48 atau $48 \%$. sedangkan sisanya $52 \%$ dipengaruhi oleh variabel lain yang tidak dimasukkan ke dalam penelitan ini.

\section{Uji Hipotesis (Uji t)}

Tabel 9. Uji Hipotesis

\begin{tabular}{ccc}
\hline Variabel & \multicolumn{1}{c}{$\mathrm{T}_{\text {hitung }}$} & Sig \\
\hline Murabahah & .448 & .657 \\
\hline Musyarakah & -.577 & .568 \\
\hline
\end{tabular}

Sumber : Data Olahan (2019)

Besarnya angka $t_{\text {tabel }}$ dengan ketentuan $\alpha$ $=0,05$ sehingga diperoleh nilai $t_{\text {tabel }}$ sebesar 2.032, Maka dapat diketahui pengaruh masing-masing variabel sebagai berikut:

1. Variabel murabahah terhadap ROA

Dari tabel koefisien diperoleh nilai $\mathrm{t}_{\text {hitung }}=$ 0,448 yang artinya $t_{\text {hitung }}<\quad t_{\text {tabel }}$ $(0,448<2.032) \quad$ dengan signifikansi 0,657>0,05 maka $\mathrm{H}_{1}$ diterima dan $\mathrm{H} \alpha$ ditolak artinya secara parsial tidak terdapat pengaruh negatif signifikan antara murabahah terhadap ROA atau murabahah berpengaruh signifikan positif terhadap ROA.

2. Variabel musyarakah terhadap ROA Dari tabel koefisien diperoleh nilai $t_{\text {hitung }}=$ -0.577 yang artinya $t_{\text {hitung }}<t_{\text {tabel }} \quad(-$ $0,577<2.032) \quad$ dengan signifikansi 0,568>0,05 maka $\mathrm{H}_{1}$ diterima dan $\mathrm{H} \alpha$ ditolak sebab $t_{\text {hitung }}<t_{\text {tabel }}$ dan $\operatorname{sig}_{t}>\alpha$ sehingga dapat disimpulkan bahwa secara parsial musyarakah berpengaruh negatif signifikan terhadap ROA. 
2020, Jurnal Tabarru' : Islamic Banking and Finance 3 (1) : 48 - 56

Uji Analisis Regresi Linier Berganda

Tabel 8. Uji Analisis Linear Berganda

\begin{tabular}{ccc}
\hline Variabel & \multicolumn{2}{c}{ Unstandardized Coefficients } \\
\hline Konstanta & -.301 & .819 \\
\hline Murabahah & .083 & .000 \\
\hline Musyarakah & -.107 & .000 \\
\hline
\end{tabular}

Sumber : Data Olahan (2019)

1. Konstanta sebesar $-0,301$ artinya jika murabahah dan musyarakah tidak ada maka ROA sebesar -0,301.

2. Koefisien regresi $\mathrm{X} 1$ sebesar 0,083 artinya setiap kenaikan satu satuan murabahah akan meningkatkan ROA sebesar 0,083. Dan sebaliknya, setiap penurunan satu satuan murabahah, akan menurunkan ROA sebesar 0,083, dengan anggapan bahwa X2 tetap.

3. Koefisien Regresi X2 sebesar -0.107 artinya setiap kenaikan satu satuan musyarakah akan meningkatkan ROA sebesar -0.107. Dan sebaliknya setiap penurunan satu satuan musyarakah, akan menurunkan ROA sebesar -0.107 dengan anggapan bahwa X1 tetap. Tanda (+) menunjukkan arah hubungan yang searah sedangkan tanda (-) menunjukkan arah hubungan yang berbanding terbalik antar variabel independen $(\mathrm{X})$ dengan variabel dependen $\mathrm{Y}$.

$$
\begin{aligned}
& Y=a+b_{1} X_{1}+b_{2} X_{2}+e \\
& Y=-0,301+0,083 X 1-0,107 X 2+52
\end{aligned}
$$

\section{PEMBAHASAN}

\section{Pengaruh Pembiayaan Murabahah terhadap Profitabilitas pada Bank Umum Syariah}

Hasil penelitian menunjukan bahwa pembiayaan murabahah berpengaruh signifikan dan positif terhadap profitabilitas (ROA). Nasabah memperoleh dana dari bank untuk membeli kebutuhan profuktif maupun konsuntif dan bank mendapatkan keuntungan dari pembiayaan murabahah, pendapatan yang diproleh akan diprehitungkan kedalam laba bank sehingga laba tersebut dapat mempengaruhi perhitungan tingkat profitabilitas (ROA) pada bank. Hasil penelitian ini sesuai dengan penelitian yang dilakukan oleh Fadholi (2015) bahwa pembiayaan murabahah berpengaruh signifikan dan positif terhadap profitabilitas (ROA) dan penelitian puteri, dkk (2014) bahwa pembiayaan murabahah berpengaruh signifikan dan positif terhadap profitabilitas (ROA) hasil penelitian ini tidak sesuai dengan penellitian yang dilakukan oleh Sari dan Afif (2015) bahwa pembiayaan murabahah berpengaruh signifikan dan negatifterhadap profitabilitas (ROA).

\section{Pengaruh Pembiayaan Musyarakah terhadap Profitabilitas pada Bank Umum Syariah}

Hasil penelitian menunjukan bahwa pembiayaan musyarakah berpengaruh signifikan dan negatif terhadap profitabilitas (ROA). karena pendapatan atau keuntungan yang diproleh dari usaha sesuai modal yang disalurkan, apabila modal yang disalurkan bersar, maka keuntungan juga besar. Hasil penelitian ini tidak sesuai dengan penelitian yang dilakukan oleh sari dan Afif (2015) yang menunjukkan bahwa pembiayaan musyarakah berpengaruh signifikan dan positif terhadap profitabilitas (ROA).

\section{KESIMPULAN}

Berdasarkan dari hasil penelitian dan pembahasan di atas, maka kesimpulan dari penelitian ini adalah:

1) Pembiayaan murabahah berpengaruh signifikan dan positif terhadap profitabilitas (ROA) pada bank umum syariah.

2) Pembiayaan musyarakah berpengaruh signifikan dan negatif terhadap profitabilitas (ROA) pada bank umum syariah.

3) Secara simultan, Pembiayaan murabahah dan musyarakah berpengaruh signifikan dan positif terhadap profitabilitas (ROA) pada bank umum syariah. 


\section{DAFTAR PUSTAKA}

Fadholi, Amri Dziki, 2015. Pengaruh Pembiayaan Murabahah, Musyarakah Dan Mudharabah Terhadap Profitabilitas Bank Umum Syariah (Studi Empiris Pada Bank Umum Syariah Di Indonesia Tahun 2011-2014). Skripsi Program Studi Akuntansi, Fakultas Ekonomi dan Bisnis, Universitas Muhammadiyah Surakarta.

Karim, Adiwarman A. 2008. Bank Islam: Analisis Fiqih dan Keuangan Edisi 3. Raja Grafindo Persada. Jakarta.

Muhammad. 2005. Manajemen Pembiayaan Bank Syariah. UPP AMP YKPN. Yogyakarta.

Melina, F., \& Zulfa, M. 2020. Implementasi Pembiayaan Murabahah pada Baitul Mal Wat Tamwil (BMT) Kota Pekanbaru. COSTING: Journal of Economic, Business and Accounting, 3(2), 356-364.

Puteri, Deasy Rahmi., Inten, Meutia., \& Yuniartie, Emylia. 2014. Pengaruh Pembiayaan Mudharabah, Musyarakah, Murabahah, Istishna Dan Ijarah Terhadap Profitabilitas Pada Bank Umum Syariah Di Indonesia. Jurnal Penelitian dan Pengembangan Akuntansi, Vol. 8, No. 1.

Sari, Mulia., \& Afif, M. Nur. 2015. Pengaruh Pembiayaan Mudharabah, Pembiayaan Musyarakah, Dan Pembiayaan Murabahah Terhadap Profitabilitas Pada Bank Syariah Manidiri Dan Bank Muamalat Indonesia (Studi Pada Bank Umum Syariah Yang Terdaftar Di Bank Indonesia Periode Triwulan I 2007- Triwulan Iv 2014). AKUNIDA, Vol. 2, No. 1.

Sjahdeini, Sutan Remy. 1999. Perbankan Syariah. Pustaka Utama Grafiti. Jakarta.
Sugiyono. 2014. Metode Penelitian Pendidikan Pendekatan Kuantitatif, Kualitatif, dan $R \& D$. Alfabeta. Bandung

Usman, Husaini, dan Akbar, Purnomo Setiadi. 2008. Pengantar Statistika. Bumi Aksara. Jakarta.

Wiroso, Sofyan. S Harahap \& Yusuf, Muhammad. 2010. Akuntansi Perbankans Syariah-PSAK Syariah Baru. LPFE Usakti. Jakarta. 